\title{
Trends of Transformation Characteristics of Ground-Level Ozone in Urban Peninsular Malaysia
}

\author{
Hasifah Abdul Aziz, Norrimi Rosaida Awang, Mohamad Faiz Mohd Amin
}

\begin{abstract}
Ozone $\left(\mathrm{O}_{3}\right)$ is the second prominent air pollution in Malaysia. The annual variation of ozone concentration depends upon several conditions such as the sources of its precursor, the land use type and meteorological parameter. This study aims to understand the trends and issues of transformation characteristics of $\mathrm{O}_{3}$ in 4 urban area (Shah Alam, Kajang, Johor Bahru and Kota Bharu) during specific critical conversion time (CCT) as well as to introduce the critical transformation time (CTT) of $\mathrm{O}_{3}$ in 4 selected continuous air quality monitoring stations (CAQMS) from the year 2000 to 2011. The identification of CTT for $\mathrm{O}_{3}$ formation was identified occurring between 8.00 a.m and 11.00 a.m., and the $\mathrm{O}_{3}$ uni-modal peaks usually after CTT at approximately between 12.00 p.m and 4.00 p.m. The results indicated that the CTT of $\mathrm{O}_{3}$ in the Kota Bharu is slightly earlier occurring between 8.00 a.m to 10.00 a.m whereas Shah Alam, Kajang and Johor Bahru the CTT later occurring between 10.00 a.m to 11.00 a.m. Only Kota Bharu recorded data was below 100 part per billion volume (ppbv), while Shah Alam, Kajang and Johor have recorded exceedances above 100 ppbv. This research elucidates that CTT is adequate to control ozone concentration. Ozone might exceed Recommended Ambient Air Quality Guideline (RMAAQC) unless nitrogen emissions are adequately managed, due to the detrimental effects for those who are at risk of respiratory health problems resulting from air pollution.
\end{abstract}

Index Terms: Diurnal variations, ozone fluctuation, precursor, secondary air pollutant.

\section{INTRODUCTION}

The unpolluted Earth's atmosphere is a mixture of gases consisting of nitrogen $\left(\mathrm{N}_{2}\right)$ and Oxygen $\left(\mathrm{O}_{2}\right)$, comprising approximately $78 \%$ and $21 \%$ respectively of atmospheric mass and volume. The $1 \%$ remaining consists of a number of trace gases. Contamination of the air began to be affected by human activities with the introduction of gas or particulate-phase substances or energy forms (heat, noise, radioactivity) so that the locally, regionally, or globally altered atmosphere may pose harm to humans, biological systems, materials or the atmosphere itself [1]. Many cases of air pollution problems affecting the world are of local or near-field origin and hence amenable to local fixes/solutions [2]. Example of these includes severe urban pollution by nitrogen oxide (the precursor of ground-level ozone) or particle matter. Both can be solved, at least partially, by curbing local scale emissions from vehicles, factories and

Revised Version Manuscript Received on September 16, 2019.

Hasifah Abdul Aziz, Faculty of Earth Science, Universiti Malaysia Kelantan, Jeli Campus, Jeli, Kelantan, Malaysia

Norrimi Rosaida Awang, Faculty of Earth Science, Universiti Malaysia Kelantan, Jeli Campus, Jeli, Kelantan, Malaysia

M. F. M. Amin, Faculty of Earth Science, Universiti Malaysia Kelantan, Kelantan, Jeli Campus, Jeli, Kelantan, Malaysia. power plants. In [2] has reported that researchers must find the particles that are most dangerous to health in each place so policies can reduce levels of those pollutants first. Ground-level ozone $\left(\mathrm{O}_{3}\right)$ pollution is the second significant prominent air pollution in Malaysia [3].

Troposphere ozone, otherwise known as ground-level ozone, is formed in the atmosphere by complex photochemical reactions involving precursors; the oxides of nitrogen and volatile organic compounds [4], [5]. Ozone becomes harmful at ground level as its unstable and reactive oxidant that can deposit onto most surfaces including biological tissues, for example, lungs, eyes or plants [6], [7]. Ozone form from its precursors; both nitric oxide (NO) and nitrogen dioxide $\left(\mathrm{NO}_{2}\right)$ are directly involved in $\mathrm{O}_{3}$ photochemical reactions to produce $\mathrm{O}_{3}$. The lifetime of these precursors, the rates of their reaction in the atmosphere and the lifetime of $\mathrm{O}_{3}$ in the troposphere combine to make tropospheric $\mathrm{O}_{3}$ a regional-global scale problem [5].

The concentration of other pollutants (its precursor) is known to cause ozone formation, the extent of which could be different depending on the specific land use categories, e.g. urban, suburban and rural. The diurnal cycles of surface ozone have a uni-modal shape, which is controlled by various processes including photochemistry, physical/chemical removal, and the rate of deposition and transport [9], [10]. In Malaysia, a number of previous studies have reported understanding the critical transformation characteristics of $\mathrm{O}_{3}$ using $\mathrm{NO}_{2}$ photolysis rate [8]. The critical conversion time (CCT) could be utilised to explain the various fluctuation characteristics of $\mathrm{O}_{3}$ and predict their diurnal variations. Literature has emerged that shows the entire process of photochemical reactions which involve $\mathrm{NO}_{2}$ photolysis and NO titration reactions where it can determine the CCT of precursors to $\mathrm{O}_{3}$ [10], [11]. This study, therefore, set out to focus on trends of critical transformation time (CTT) characteristics where the exact time range of ozone transformation is in the highest rate in urban peninsular Malaysia. 


\section{METHODOLOGY}

\section{A. Study area}

4 urban areas (Shah Alam, Kajang, Kota Bharu and Johor Bahru) of continuous air quality monitoring stations (CAMQS) operated by a private company, Alam Sekitar Malaysia Sdn Bhd (ASMA) hired by Department of Environment (DOE) Malaysia have been chosen in this study. Fig. 1 shows the map of the located monitoring station.

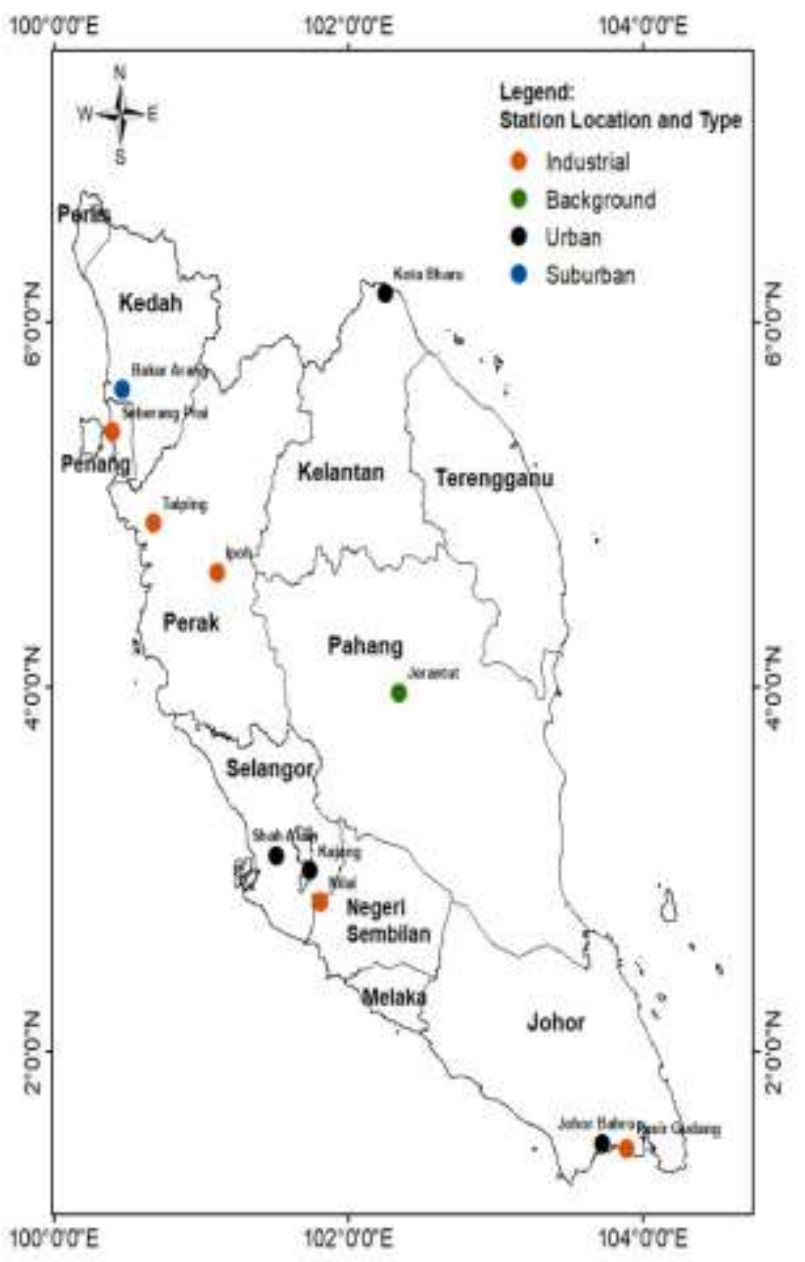

Fig. 1: Selected urban location of CAQMS in Peninsular Malaysia

\section{B. Secondary data collection}

Twelve years of continuous hourly ground-level $\mathrm{O}_{3}$ concentrations and other air pollutant levels starting from 1st January 2000 to 31st December 2011, was obtained from the Department of Environment, Malaysia.

The pre-treatment of hourly secondary data will be carried out to prepare the data for further analysis. Missing values will be directly omitted from analysis to avoid systematic error in dataset.

Hourly $\mathrm{O}_{3}$ concentrations and other two air pollutants such $\mathrm{NO}$ and $\mathrm{NO}_{2}$ will be plotted. Regular calibration of the monitoring instrument was done by ASMA for quality assurances and quality controls of the air monitoring data. According to [12], air monitoring instruments have been scheduled to have daily auto-calibration using zero air and standard gas concentration for gas monitoring such as $\mathrm{O}_{3}$ and $\mathrm{NO}_{2}$. At every two weeks interval, each of the instruments will be calibrated manually using its individual calibration gas. Before transferring to DOE, the hourly data was checked for validation. $0.6 \mathrm{ppbv}$ and $0.4 \mathrm{ppbv}$ were the lower detection limit for $\mathrm{O}_{3}$ and $\mathrm{NO}_{2}$, respectively.

\section{Ground-level ozone concentration}

The ozone data were obtained from the air monitoring station by DOE, which is managed by ASMA. The instrument used at the monitoring station was UV Absorption $\mathrm{O}_{3}$ Analyzer Model 400A to measure the $\mathrm{O}_{3}$ concentration. Beer-Lambert law was applied in the system to measure low ranges of $\mathrm{O}_{3}$ in ambient air. The $\mathrm{O}_{3}$ detection range of the analyser started from $0-100 \mathrm{ppb}$ to $0-10 \mathrm{ppm}$. The ozone measurement was done when a UV light signal with a wavelength of $254 \mathrm{~nm}$ passed through the sample cell where it was absorbed in proportion to the amount of ozone present.

\section{NO2 concentration}

Similar to ozone data collection, $\mathrm{NO}_{2}$ concentration were obtained from DOE and the instrument used at the monitoring station was $\mathrm{NO} / \mathrm{NO}_{2} / \mathrm{NO}_{\mathrm{x}}$ Analyzer Model 200A. The chemiluminescence detection principle was used in the analyzer, which is coupled with state-of-art-electronics for $\mathrm{NO}_{2}$ concentration measurement. The analyzer was equipped with a minimum detection range of $0-50 \mathrm{ppb}$ to a maximum detection range of 0-20 ppm.

\section{E. Diurnal variations}

The composite diurnal plot is used to study the long-term behaviour of the $\mathrm{O}_{3}$ and its precursors. In this study, the average hourly concentration of $\mathrm{O}_{3}$, $\mathrm{NO}$ and $\mathrm{NO}_{2}$ were plotted to determine the relationship between the variables and to investigate the critical transformation time of $\mathrm{O}_{3}$ Diurnal plots help to determine the critical conversion point where the interception of $\mathrm{O}_{3}, \mathrm{NO}$ and $\mathrm{NO}_{2}$ [10]. The CCT plays an important role in diurnal plot whereby the range of CTT has been investigated.

CTT is defined as the time range where the photochemical reaction reached the peak level (uni-modal shape) from the composite diurnal plot. CTT range occurred within the CCT. Within the CCT, $\mathrm{NO}_{2}$ photolysis rate started to surpass the NO titration rate. CTT was based on the composite diurnal plots of $\mathrm{O}_{3}, \mathrm{NO}$ and $\mathrm{NO}_{2}$. The interception point of $\mathrm{O}_{3}, \mathrm{NO}$ and $\mathrm{NO}_{2}$ concentration in a diurnal plot indicated the critical conversion point and the critical transformation time was determined through the relationship of $\mathrm{O}_{3}, \mathrm{NO}$ and $\mathrm{NO}_{2}$ concentration.

\section{RESULTS AND DISCUSSION}

\section{A. Descriptive statistics}

The descriptive statistics of hourly $\mathrm{O}_{3}$ concentration from 2000 to 2011 at the 4 monitoring station; urban- Kota Bharu; KB, Shah Alam; SA, Kajang; KJG and Johor Bahru; JB using Table 1 and boxplot, illustrated below (Fig. 2). The hourly average concentrations of $\mathrm{O}_{3}$ at the monitoring stations were recorded between 13 and 20 ppbv. Shah Alam (SA) station recorded the highest average concentration of $\mathrm{O}_{3}(20 \mathrm{ppbv})$.

This was followed by Kajang (19 ppbv), Johor Bahru (14 ppbv) and Kota Bharu (13 ppbv) respectively. The highest 
maximum recorded at Kajang with maximum value up to 175 ppbv, followed by Shah Alam (174 ppbv), Johor Bahru (141 ppbv) and Kota Bharu (69 ppbv).

Table 1: Descriptive data for hourly $\mathrm{O}_{3}$ concentration from 2000 to 2011 of 4 CAQMS; KB, SA, KJG and KB

\begin{tabular}{|l|l|l|l|l|l|l|}
\hline $\begin{array}{l}\text { Loc } \\
\text { atio } \\
\mathrm{n}\end{array}$ & N total & $\begin{array}{l}\text { M } \\
\text { ea } \\
\mathrm{n}\end{array}$ & $\begin{array}{l}\text { Standard } \\
\text { Deviation }\end{array}$ & $\begin{array}{l}\text { Mini } \\
\text { mum }\end{array}$ & $\begin{array}{l}\text { Me } \\
\text { dia } \\
\mathrm{n}\end{array}$ & $\begin{array}{l}\text { Maxi } \\
\text { mum }\end{array}$ \\
\hline KB & 99602 & 13 & 10.341 & 1 & 12 & 69 \\
\hline SA & 99717 & 20 & 23.730 & 1 & 11 & 174 \\
\hline $\begin{array}{l}\text { KJ } \\
\text { G }\end{array}$ & 92047 & 19 & 21.582 & 1 & 12 & 175 \\
\hline JB & 99694 & 14 & 14.256 & 1 & 9 & 141 \\
\hline
\end{tabular}

The variations of $\mathrm{O}_{3}$ concentrations at the 4 monitoring stations because of the different background of the presence of its precursors; the oxides of nitrogen $\left(\mathrm{NO}_{\mathrm{x}}\right)$ and volatile organic compounds (VOCs) thru photochemical reactions in the presence of sunlight [11], [12].

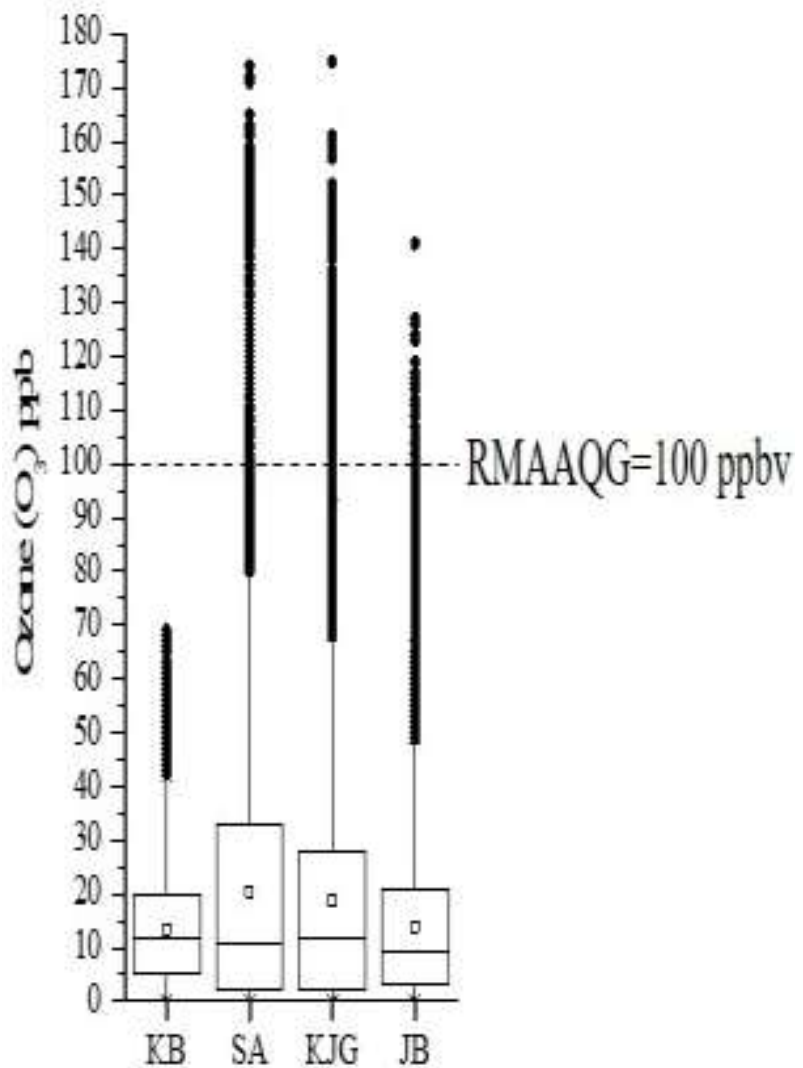

Fig. 2: Box and Whisker Plot of hourly average of $\mathrm{O}_{3}$ concentration for Kota Bharu, Shah Alam, Kajang and Johor Bahru

Results from box and whisker plot suggest that distribution of the data at $\mathrm{SA}, \mathrm{KJG}$ and $\mathrm{JB}$ were skewed to the right (median < mean), while $\mathrm{KB}$ was uniformly distributed $($ median $=$ mean $)$. The median values vary to the average $\mathrm{O}_{3}$ concentration (between +-9 ppbv and $12 \mathrm{ppbv}$ ), while the standard deviation for the dataset was between 10 and 21 ppbv for all the stations. Results of distribution have several violations of distribution assumptions of parametric tests; alternative nonparametric techniques can be used to detect long-term air pollutants when sample of data does not satisfy normal distribution assumptions. This exemplified in work undertaken by [13] demonstrates that ozone distribution in 6 monitoring station of United Kingdom are not normally distributed and hence non-parametric statistic should be used. Other than that, there were also outliers detected in each of the data set. Outliers are the data that lies far from the other value in a random sample and do not belongs to the main population. The outliers in Fig. 2 contributed from the highest $\mathrm{O}_{3}$ concentration recorded throughout the 12 years. The presence of the outliers indicated that there are certain days when the $\mathrm{O}_{3}$ transformation was much higher than the other days. Most of the maximum concentrations were outliers sources from external pollutant factors [14].

\section{B. Diurnal variations}

Diurnal plot giving the information of fluctuation of $\mathrm{O}_{3}$. Fig. 3 shows the diurnal variation of the hourly average of $\mathrm{O}_{3}$ and its precursors $\left(\mathrm{NO}\right.$ and $\mathrm{NO}_{2}$ ) at 4 continuous air quality monitoring station (CAQMS). The fluctuational behaviour of individual illustrated using composite diurnal plot (Fig. 3). Overall, $\mathrm{O}_{3}$ diurnal variations show the uni-modal shape. The increasing trend of $\mathrm{O}_{3}$ concentration after the sunrise, reaching a peak approximately between 12.00 p.m. to 4.00 p.m. Minimum concentrations were recorded in the afternoon between 7.00 p.m. to 7.a.m. The minima occurred at 8.00 a.m at all stations. Several recent studies exhibit that $\mathrm{O}_{3}$ exhibits strong diurnal variations [8], [15]-[17] at different locations. Day time surface ozone [18] and nocturnal surface ozone [17] variations depending on its precursors and meteorological conditions. The study of ozone variation is complex. In [18] have addressed some key challenge in mitigating ozone based on surface ozone. There is large difference in the frequency of total daily maximum ozone concentration between CAQMS stations that are close. Thus, in this study, critical conversion point (CCP) that show the exact time (CCT) is used to explain in more details of photochemical processes involved in fluctuational and transformation of $\mathrm{O}_{3}$. CCP and CCT can be obtained from composite diurnal plot. The different location has a different time for CCP. CCP is assumed to be the interception point between $\mathrm{O}_{3}, \mathrm{NO}_{2}$ and NO line in the composite diurnal plot [10]. Generally, at the beginning of the plot, $\mathrm{NO}_{2}$ concentration was high while $\mathrm{O}_{3}$ concentration remained low due to $\mathrm{NO}_{\mathrm{x}}$ titration during nighttime [16]. Changes started to occur when entering CCT, starting around 8.00 a.m., due to the increasing solar radiation that triggers photochemical reactions. During $\mathrm{CCT}, \mathrm{NO}_{2}$ was used up for the $\mathrm{O}_{3}$ formation. $\mathrm{CCP}$ occurred when photochemical reaction rate started to surpass $\mathrm{NO}_{\mathrm{x}}$ titration rate and it was represented by the interception point between $\mathrm{O}_{3}$ and $\mathrm{NO}_{2}$ concentration on the plot [10], [11], [19]-[21]. The $\mathrm{O}_{3}$ uni-modal peaks usually after CCT approximately between 12.00 p.m. to 4.00 p.m. 


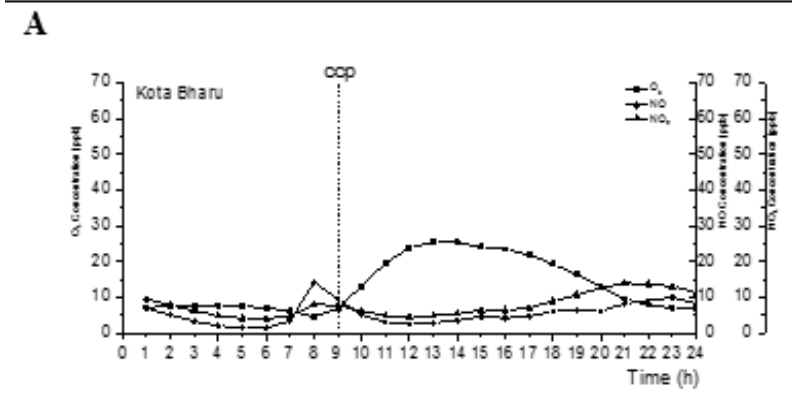

B

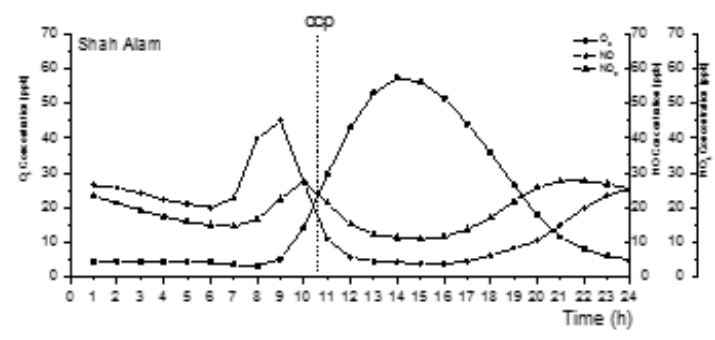

$\mathbf{C}$

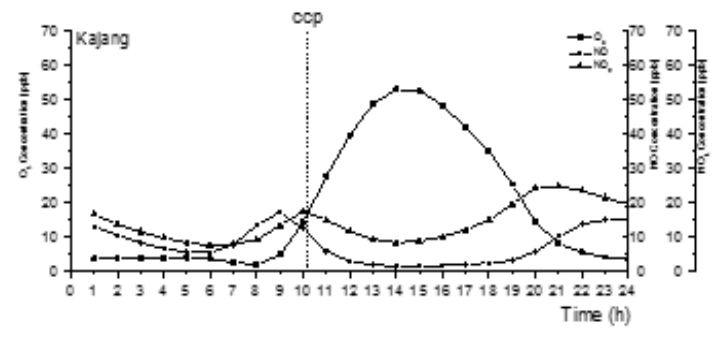

D

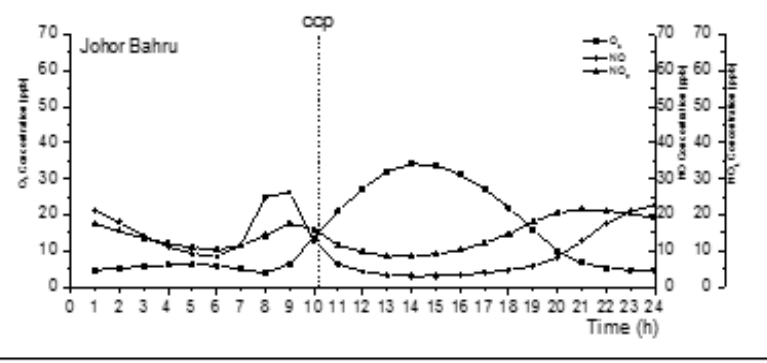

Fig. 3: Composite diurnal plot of $\mathrm{O}_{3}, \mathrm{NO}$ and $\mathrm{NO}_{2}$ concentration at urban CAQMS: (A) Kota Bharu (B)

Shah Alam (C) Kajang and (D) Johor Bahru

CCT was considered based on the photochemical reactions of $\mathrm{O}_{3}$ formation. CCT is the process where the rate of $\mathrm{NO}_{2}$ photolysis was higher than the rate of NO titration [20]. Higher rate of $\mathrm{NO}_{2}$ photolysis than $\mathrm{NO}$ titration will accumulate the $\mathrm{O}_{3}$ production [22]. Thus, CCT can be used to explain the $\mathrm{O}_{3}$ formation and destruction (Table 2) which can be used to represent diurnal the variations of $\mathrm{O}_{3}$ during daytime and nighttime.

Fig. 3 represents diurnal variations for the urban CAQMS. The CCP of each location is obtained based on the average of hourly data for 12 years. For all regions, the ozone concentration starts to decrease after the CCT time (the uni-modal peaks) around 2.00 p.m. to 5.00 p.m. The decrease of $\mathrm{O}_{3}$ is due to the decrease of UV intensity as the sun radiation starts to decline. As the ozone decrease, $\mathrm{NO}_{2}$ starts to increase (R4), the titration process. Ozone starts to decrease started at $7.00 \mathrm{pm}$ to 7.00 a.m at all locations following reactions:

$$
\begin{aligned}
& \mathrm{NO}_{2}+h v(\lambda 400 n m) \rightarrow \mathrm{NO}+\mathrm{O}(\mathrm{R} 1) \\
& \mathrm{O}+\mathrm{O}_{2}+\mathrm{M} \rightarrow \mathrm{O}_{3}+\mathrm{M}(\mathrm{R} 2) \\
& \mathrm{NO}+\mathrm{O}_{2} \rightarrow \mathrm{NO}_{2}+\mathrm{O}_{2}(R 3) \\
& \mathrm{NO}_{2}+\mathrm{O}_{3} \rightarrow \mathrm{NO}_{3}+\mathrm{O}_{2}(R 4) \\
& \mathrm{NO}_{3}+\mathrm{NO}_{2}+\mathrm{M} \leftrightarrow \mathrm{N}_{2} \mathrm{O}_{5}+\mathrm{M}(\mathrm{R} 5) \\
& \mathrm{N}_{2} \mathrm{O}_{5}+\mathrm{H}_{2} \mathrm{O} \rightarrow 2 \mathrm{HNO}_{3}(\mathrm{R} 6)
\end{aligned}
$$

During nighttime, the reaction between $\mathrm{O}_{3}$ and $\mathrm{NO}_{2}$ yield nitrate $\left(\mathrm{NO}_{3}\right)$ radicals through $\mathrm{R} 4$. The produced $\mathrm{NO}_{3}$ radicals directly react with $\mathrm{NO}_{2}$, producing dinitrogen pentoxide $\left(\mathrm{N}_{2} \mathrm{O}_{5}\right)$. It is unstable and will dissociate back to $\mathrm{NO}_{2}$ and $\mathrm{NO}_{3}$ radicals (R5). However, $\mathrm{N}_{2} \mathrm{O}_{5}$ may also undergo reaction with $\mathrm{H}_{2} \mathrm{O}$ to form nitric acid $\left(\mathrm{HNO}_{3}\right)$. Increasing water vapour in nighttime relatively increase the $\mathrm{RH}$ will enhance the formation of nitric acid, $\mathrm{HNO}_{3}$ (R6). $\mathrm{HNO}_{3}$ is highly soluble in water and deposit thru precipitation as acid rain [7], [23]. Limited nighttime $\mathrm{NO}_{2}$ directly reduce the reaction rates of R4 and R5. The decline continues until it reaches a stable concentration throughout the nights starting at 11.00 p.m. The interruption of removal reactions allowed $\mathrm{O}_{3}$ to remain in the atmosphere [16]. The high concentration of $\mathrm{NO}_{2}$ will enhance the reaction in R4, R5 and R6 to destruct the $\mathrm{O}_{3}$.

The monthly diurnal variation analysis revealed the second peaks of surface ozone during night time happened at more than $50 \%$ of all CAQMS occurring around 3.00 a.m. to 5.00 a.m and the ratio mean of nighttime to daytime ozone concentration was the highest in the east coast region and lowest in the central region while the other regions were in average. This could explain the highest is due to horizontal transport while the lowest is due to titration [17].

\section{Critical Transformation Time (CTT)}

CTT is introduced to assess the trends of ozone transformation for urban area. The results showed that the CTT in Table 2, which was between 8.00 a.m. and 11.00 a.m. From the result, it was observed that the CTT at Kota Bharu occurred between \pm 8.00 a.m to 10.00 a.m. while CCT at Shah Alam, Kajang and Johor Bahru occurred between \pm 10.00 a.m to 11.00 a.m. These 4 locations are in the same categories of land use however the range of CTT in Kota Bharu slightly earlier. During $\mathrm{CTT}, \mathrm{O}_{3}$ concentration only started to accumulate due to the increased rate of $\mathrm{NO}_{2}$ photolysis at a point time called CCT that indicated the highest rate of photochemical reaction at that point. The diurnal plot showed that the $\mathrm{NO}_{2}$ concentration decreased after CCP while $\mathrm{O}_{3}$ concentration increased. This indicated that the transformation of $\mathrm{NO}_{2}$ to $\mathrm{O}_{3}$ occurred rapidly, which lead to accumulation of $\mathrm{O}_{3}$ and concentration of $\mathrm{O}_{3}$ increased. Hence the mean value both $\mathrm{NO}_{2}$ and $\mathrm{NO}$ were higher during CCT [10]. The $\mathrm{O}_{3}$ maxima happened after CCT, usually between 12.00 p.m. and 4.00 p.m. which is at different time range. 
Table 2: Critical conversion time (CCT) and critical transformation time (CTT) based on composite diurnal plots at 4 CAQMS

\begin{tabular}{|c|c|c|c|c|}
\hline Year & \multicolumn{4}{|c|}{ Critical Conversion Time (CCT) } \\
\hline & \multicolumn{4}{|l|}{ Urban } \\
\hline Location & $\begin{array}{l}\text { Shah } \\
\text { Alam }\end{array}$ & Kajang & $\begin{array}{l}\text { Johor } \\
\text { Bahru }\end{array}$ & $\begin{array}{l}\text { Kota } \\
\text { Bharu }\end{array}$ \\
\hline 2000 & 10.45 & 10.00 & 10.30 & 9.10 \\
\hline 2001 & 10.55 & 10.00 & 10.20 & 9.10 \\
\hline 2002 & 10.55 & 10.00 & 10.00 & 9.10 \\
\hline 2003 & 10.55 & 10.00 & 10.20 & 9.15 \\
\hline 2004 & 10.55 & 10.00 & 10.15 & 9.05 \\
\hline 2005 & 10.45 & 10.00 & 10.15 & 8.30 \\
\hline 2006 & 10.15 & 10.00 & 10.10 & 8.50 \\
\hline 2007 & 10.15 & 10.00 & 10.00 & 8.50 \\
\hline 2008 & 10.45 & 10.10 & 10.00 & 9.00 \\
\hline 2009 & 10.30 & 10.00 & 10.10 & 9.30 \\
\hline 2010 & 10.30 & N/A & 10.15 & 9.00 \\
\hline 2011 & 10.30 & N/A & 10.00 & 8.30 \\
\hline $\begin{array}{l}\text { Critical } \\
\text { Transformation } \\
\text { Time (CTT) }\end{array}$ & $\begin{array}{l}10.00 \text { a.m } \\
\text { to } 11.00 \\
\text { a.m }\end{array}$ & $\begin{array}{l}10.00 \\
\text { a.m to } \\
11.00 \\
\text { a.m }\end{array}$ & $\begin{array}{l}10.00 \\
\text { a.m to } \\
11.00 \\
\text { a.m }\end{array}$ & $\begin{array}{l}8.00 \\
\text { a.m to } \\
10.00 \\
\text { a.m }\end{array}$ \\
\hline
\end{tabular}

\section{CONCLUSION}

In conclusion, CTT can be used to characterize the behaviour of ground-level ozone. The concentration of $\mathrm{O}_{3}$ pollution depending on its ambient environment decided by their transport in the atmosphere depending on atmospheric dispersion or diffusion. The rate of this process depending on atmospheric turbulence, which varies with both location and time. Therefore, pollutants and particulates released from industrial, vehicular and other sources into the atmosphere get dispersed by different mechanisms governed by meteorological parameters. The CTT of $\mathrm{O}_{3}$ has the information of source reaching the receptor location and information of the local meteorology. The parameters of interest are the local wind speed, wind direction and temperature vary from time-to-time becomes essential for interpretation of air quality data and modelling of pollutant in the atmosphere.

\section{ACKNOWLEDGMENT}

We would like to thank the Universiti Malaysia Kelantan in support of this study through the Skim Geran Penyelidikan Jangka Pendek - SGJP (R/SGJP/A08.00/00874A/ 001/2018/000497).

\section{REFERENCES}

1. T. Godish, W. T. Davis, and J. S. Fu, Air Quality. Florida: CRC Press, 2014

2. S. J. Lovelock, Comment-Air pollution: A global problem needs local fixes. Available: https://www.nature.com/articles/d41586-019-01960-7.

3. Department of Environment Malaysia, Laporan kualiti alam sekeliling 2017. Available: https://www.doe.gov.my/portalv1/awam/maklumatumum /laporan-jabatan-alam-sekitar.

4. H. Akimoto, "Global air quality and pollution," Science, 302(5651), 2003, pp. 1716-1719.

5. P. J. Young, V. Naik, A. M. Fiore, A. Gaudel, J. Guo, M. Y. Lin, J. Neu, D. Parrish, H. E. Reider, J. L. Schnell, and
S. Tilmes, "Tropospheric ozone assessment report: Assessment of global-scale model performance for global and regional ozone distributions, variability, and trends," Elementa: Science of the Anthropocene, 6(1), 2018, pp. 1-49.

6. E. A. Ainsworth, "Understanding and improving global crop response to ozone pollution," Plant Journal, 90(5), 2017, pp. 886-897.

7. D. Fowler, M. Amann, F. Anderson, M. Ashmore, P. Cox M. Depledge, D. Derwent, P. Grennfelt, N. Hewitt, O. Hov, and M. Jenkin, Ground-level ozone in the $21 \mathrm{st}$ century: Future trends, impacts and policy implications. Science Policy Report, London: The Royal Society, 2008.

8. N. R. Awang, M. Elbayoumi, N. A. Ramli, and A. S. Yahaya, "Diurnal variations of ground-level ozone in three port cities in Malaysia," Air Qual. Atmos. Heal., 9(1), 2016, pp. 25-39.

9. N. A. Ghazali, N. A. Ramli, A. S. Yahaya, N. F. F. M. Yusof, N. Sansuddin, and W. A. Al Madhoun, "Transformation of nitrogen dioxide into ozone and prediction of ozone concentrations using multiple linear regression techniques," Environ. Monit. Assess., 165(14), 2010, pp. 475-489.

10. N. R. Awang, M. Elbayoumi, N. A. Ramli, and A. S Yahaya, "The influence of spatial variability of critical conversion point $(\mathrm{CCP})$ in production of ground level ozone in the context of tropical climate," Aerosol Air Qual. Res., 16(1), 2016, pp. 153-165.

11. M. T. Latif, D. Dominick, F. Ahamad, N. S. Ahamad, M F. Khan, L. Juneng, C. J. Xiang, M. S. Nadzir, A. D Robinson, M. Ismail, and M. I. Mead, "Seasonal and long term variations of surface ozone concentrations in Malaysian Borneo," Sci. Total Environ., 573, 2016, pp. 494-504.

12. N. Banan, M. T. Latif, L. Juneng, and F. Ahamad, "Characteristics of surface ozone concentrations at stations with different backgrounds in the Malaysian Peninsula," Aerosol Air Qual. Res., 13(3), 2013, pp. 1090-1106.

13. S. Munir, H. Chen, and K. Ropkins, "Non-parametric nature of ground-level ozone and its dependence on nitrogen oxides (NOx): A view point of vehicular emissions," WIT Trans. Ecol. Environ., 147, 2011, pp 93-104.

14. A. Azhari, M. T. Latif, and A. F. Mohamed, "Road traffic as an air pollutant contributor within an industrial park environment," Atmos. Pollut. Res., 9(4), 2018, pp. 680-687.

15. N. R. Awang, N. A. Ramli, S. Shith, N. S. Zainordin, and H. Manogaran, "Transformational characteristics of ground-level ozone during high particulate events in urban area of Malaysia," Air Quality, Atmosphere and Health, 11(6), 2018, pp. 715-727.

16. N. R. Awang, N. A. Ramli, A. S. Yahaya, and M. Elbayoumi, "High nighttime ground-level ozone concentrations in Kemaman: No and NO2 concentrations attributions," Aerosol Air Qual. Res., 15(4), 2015, pp. $1357-1366$

17. M. F. Yusoff, M. T. Latif, L. Juneng, M. F. Khan, F. Ahamad, J. X. Chung, and A. A. A. Mohtar, "Spatio-temporal assessment of nocturnal surface ozone in Malaysia," Atmos. Environ., 207, 2019, pp. 105-116.

18. F. Ahamad, M. T. Latif, M. F. Yusoff, M. F. Khan, and L. Juneng, "So near yet so different: Surface ozone at three sites in Malaysia," IOP Conf. Ser. Earth Environ. Sci., 228(1), 2019, pp. 1-5. 
19. A. K. Gorai, P. B. Tchounwou, and G. Mitra, "Spatial variation of ground level ozone concentrations and its health impacts in an urban area in India," Aerosol Air Qual. Res., 17(4), 2017, pp. 951-964.

20. N. R. Awang, N. A. Ramli, A. S. Yahaya, and M. Elbayoumi, "Multivariate methods to predict ground level ozone during daytime, nighttime, and critical conversion time in urban areas," Atmos. Pollut. Res., 6(5), 2015, pp. 726-734.

21. N. R. Awang, N. A. Ramli, A. S. Yahaya, and M Elbayoumi, "Multivariate methods to predict ground level ozone during daytime, nighttime, and critical conversion time in urban areas," Atmospheric Pollution Research, 6(5), 2015, pp. 726-734.

22. A. Tiwary and J. Colls, Air Pollution: Measurement, Modelling and Mitigation. Florida: CRC Press, 2018.

23. P. S. Monks, A. T. Archibald, A. Colette, O. Cooper, M. Coyle, R. Derwent, D. Fowler, C. Granier, K. S. Law, D. S. Stevenson, and O. Tarasova, "Tropospheric ozone and its precursors from the urban to the global scale from air quality to short-lived climate forcer," Atmos. Chem. Phys., 14(23), 2015, pp. 8889-8973. 